\title{
DINAMIKA PENDIDIKAN AGAMA KRISTEN DI TENGAH WABAH CORONA: SEBUAH REFLEKSI BERDASARKAN PENGAJARAN PAULUS DALAM GALATIA 6:2
}

\author{
Adida Casriarno ${ }^{1}$, Demianus Nataniel ${ }^{2}$ \\ Sekolah Tinggi Theologia Abdiel ${ }^{1}$, Sekolah Tinggi Theologia Abdiel ${ }^{2}$ \\ adidacasriarno@gmail.com ${ }^{l}$,demianusnataniel@gmail.com ${ }^{2}$
}

\begin{abstract}
Abstrak
Artikel ini membahas bagaimana tradisi pengajaran Paulus dalam Galatia 6:2 dapat menginspirasi gereja-gereja dalam melaksanakan pendidikan agama Kristen di tengah masyarakat majemuk di Indonesia, yang tengah menghadapi pandemi virus Corona. Dengan mengangkat ideologi imperialis sebagai latar belakang permasalahan yang tengah dihadapi oleh Paulus dan jemaat-jemaat di Galatia, serta hakikat dan tujuan Pendidikan Agama Kristen maka gereja-gereja dipanggil untuk memiliki kreativitas dalam menghadapi pandemi tersebut. Kreativitas yang dapat dikembangkan adalah menjadikan budaya gotong royong sebagai dialog yang membebaskan dan menyejahterakan. Kreativitas ini dapat muncul ketika masyarakat mampu diajak bersikap positif dalam menghadapi situasi sulit.
\end{abstract}

Kata kunci: dialog; Galatia 6:2; gotong royong; pandemi virus Corona; Paulus; Pendidikan Agama Kristen

\begin{abstract}
This article discusses on how Paul's teaching in Galatians 6: 2 can inspire the churches in implementing the praxis of the Christian Religious Education amidst the plural society in Indonesia, which is facing the coronavirus pandemic. By exploring imperialist ideology as the background of the problems that Paul and the Galatians faced and the nature and purpose of the Christian Religious Education, the churches are called to have creativity in struggling with the Corona pandemic. The creativity that can be developed is to make mutual cooperation (gotong royong) tradition as liberating and prospering dialogue. This creativity can emerge when people are able to be positive in facing difficult situations.
\end{abstract}

Keywords: dialogue; Galatian 6:2; mutual cooperation; Coronavirus; Paul; Christian Religious Education

\section{Pendahuluan}

Hampir seluruh masyarakat di dunia saat ini merasakan kekuatiran dan kegelisahan yang mendalam. Kegelisahan dan kekuatiran itu muncul karena adanya pandemi yang sedang melanda dunia. Pandemi berupa virus Corona atau biasa disebut Covid-19 memberi dampak yang luar biasa. Lembaga survei SMRC (Saiful Mujani Research \& Consulting) mengungkapkan bahwa pandemi tersebut sangat mempengaruhi perekonomian warga, khususnya yang bekerja di sektor informal dan kelompok pekerja yang mengandalkan pendapatan harian ${ }^{1}$. Pandemi ini tidak hanya mempengaruhi sektor perekonomian warga,

1 Amirullah, "Survei SMRC: 77 Persen Publik Merasa Covid-19 Ancam Penghasilan," Tempo (Jakarta, April 17, 2020), https://nasional.tempo.co/read/1341315/jokowi-minta-pengendalian-covid-19-dipulau-jawa-makin-efektif. 
tetapi juga mempengaruhi dunia pendidikan, termasuk di Indonesia. Penyebaran virus Corona mengharuskan proses KBM (Kegiatan Belajar Mengajar) dilakukan secara online. Artinya semua lembaga pendidikan mulai dari tingkat PAUD sampai perguruan tinggi mengharuskan siswa-siswinya tetap berada di rumah dan melaksanakan proses belajar mengajar dengan memanfaatkan jaringan internet. Selain itu, penyebaran virus corona juga mempengaruhi kegiatan beribadah warga. Pemerintah mengharuskan semua warga untuk melakukan ibadah dari rumah, baik itu Islam, Kristen, Budha, Konghucu dan lain sebagainya, hal itu bertujuan untuk memutus mata rantai penyebaran virus Corona atau Covid-19. Pertanyaannya adalah apakah pandemi yang melanda masyarakat dunia saat ini hanya membawa dampak negatif bagi peradaban dunia? Adakah pengaruh positif yang dapat dirasakan masyarakat, khususnya umat beragama dalam menghadapi wabah ini?

Berdasarkan pola pengajaran Paulus sebagaimana tercermin dalam Galatia 6:2, dan dengan mempertimbangkan hakikat dan tujuan Pendidikan Agama Kristen maka tulisan ini ingin menunjukkan bahwa wabah Covid-19 membuka cakrawala baru bagi masyarakat beragama di Indonesia untuk meningkatkan kerja sama dan kepeduliannya satu sama lain tanpa memandang suku, agama, ras, dan golongan. Untuk sampai pada kesimpulan tersebut maka setelah diuraikan secara singkat mengenai bagaimana persoalan-persoalan muncul menyusul wabah virus Corona, berturut-turut akan dibahas hakikat dan Pendidikan Agama Kristen dan diteruskan dengan mengulas pola pengajaran Paulus dalam Galatia 6:2 yang mengajak jemaat untuk bertolong-tolongan menanggung beban di tengah kesulitan yang dihadapi bersama. Berdasarkan dua hal tersebut akan diangkat pentingnya dialog dalam pendidikan agama di tengah masyarakat majemuk yang diteruskan dengan gotong royong sebagai bentuk dialog yang membebaskan dan menyejahterakan.

\section{Wabah Corona di tengah Isu-Isu SARA}

Salah satu persoalan yang selama ini dihadapi oleh masyarakat Indonesia adalah pluralisme, termasuk kemajemukan agama. Kepelbagaian yang menjadi ciri masyarakat di negara Indonesia sejatinya merupakan keindahan. Namun demikian ciri khas ini dapat menjadi potensi yang membahayakan keutuhan bangsa jika tidak dikelola dengan baik dan benar. Alih-alih menjadi pendorong dan kekuatan bagi bangsa Indonesia untuk membangun, kepelbagaian justru sering dimanfaatkan untuk meraih keuntungan sepihak dan mengabaikan kepentingan bersama sebagai sebuah bangsa. Hal ini terlihat ketika unsur-unsur SARA dijadikan alat kampanye, baik dalam PEMILUKADA maupun dalam 
PEMILU Presiden di Indonesia beberapa waktu lalu. Sisa-sisa perseteruan dengan melibatkan unsur-unsur SARA tersebut masih terlihat jelas dalam berbagai percakapan di Sosial Media, bahkan ketika seluruh dunia termasuk Indonesia menghadapi wabah Covid19. Hujatan-hujatan dan sindirian juga muncul seiring merebaknya wabah virus Corona. Fakta bahwa virus Corona pertama kali ditemukan dan menyerang wilayah di negara Tiongkok dijadikan oleh pihak-pihak tertentu sebagai alat dan senjata politik untuk dapat memberi keuntungan bagi diri sendiri sekaligus menyerang secara emosional pihak lain. Bukan hanya Donald Trumph yang disinyalir memanfaatkan fakta tersebut untuk menyerang negara lain sebagai lawan dalam pertarungan bisnis global, tetapi ada juga masyarakat di Indonesia yang menggunakannya untuk mendiskreditkan masyarakat dari etnis tertentu di Indonesia.

Terlepas dari pemanfaatan situasi sulit untuk kepentingan jangka pendek bagi pribadi dan kelompok/ golongan, masyarakat dunia saat ini memang sedang menghadapi wabah bersama. Demikian juga dengan masyarakat di negara Indonesia. Sampai sekarang belum ditemukan vaksin untuk mengatasinya. Semua orang mengalami kesulitan dan penderitaan. Kesulitan dan penderitaan yang diakibatkan oleh virus tersebut salah satunya adalah kematian. Di Indonesia saja, hingga saat ini telah lebih dari delapan ratus orang meninggal dunia. Artinya ada duka cita yang dialami oleh banyak orang. Kematian ini tidak memandang sasaran. Siapapun, mulai dari kalangan masyarakat bawah hingga orangorang dari kalangan atas. Orang-orang yang berpendidikan tinggi dan memiliki harta banyak juga mengalami akibatnya. Situasi ini tentu menjadi penting untuk dicermati mengingat kematian menjadi sesuatu yang sangat dekat bagi siapapun. Kematian menjadi sosok yang siap menjemput siapapun tanpa memandang suku, agama, ras, dan golongan.

Masalah kedua yang sangat dirasakan masyarakat adalah berkenaan dengan ekonomi. Penyebaran virus Corona yang masif mendorong pemerintah di negara-negara terpapar harus memberlakukan peraturan yang membuat roda perekonomian tersendat. Pemerintah-pemerintah di seluruh dunia mengeluarkan dana yang sangat besar untuk mengatasi pandemi Covid-19, sementara itu banyak masyarakat penghasilannya mulai berkurang, bahkan mengalami Pemutusan Hubungan Kerja (PHK). Ancaman kematian ditambah dengan merosotnya kekuatan ekonomi menimbulkan kekhawatiran dan ketakutan yang mendalam. Situasi ini menyebabkan jumlah orang dengan gangguan jiwa meningkat. 
Fakta ini antara lain disampaikan oleh Kepala Dinas Kesehatan di Jawa Barat, Berli Hamdani $^{2}$.

Masalah berikutnya adalah berkaitan dengan pendidikan dan keagamaan. Kegiatankegiatan sekolah dan keagamaan yang biasanya dilakukan secara bersama-sama dengan banyak orang mulai terkendala setelah pemerintah mengeluarkan kebijakan yang meminta agar masyarakat belajar dan beribadah di rumah saja. Untuk masalah pendidikan maka tantangannya adalah sarana telekomunikasi melalui internet. Bagi masyarakat yang sudah terbiasa dengan model pendidikan jarak jauh dan e-learning, situasinya tidak terlalu sulit. Berbeda dengan sekolah-sekolah yang guru dan siswanya belum memiliki jaringan telekomunikasi yang memadai.

Kebijakan yang awalnya lebih menimbulkan pro dan kontra di tengah masyarakat adalah dalam hal keagamaan. Dalam tayangan televisi swasta di Indonesia ada orang yang tetap bersikeras melakukan kegiatan keagamaan secara bersama-sama dengan alasan bahwa ibadah secara berjamaah atau bersama-sama di rumah-rumah ibadah seperti gereja dan masjid hukumnya wajib. Kewajiban tersebut merupakan perintah Tuhan yang tentunya lebih tinggi daripada anjuran pemerintah.

Situasi sebagaimana dipaparkan tersebut mendorong semua pihak termasuk gereja untuk memaknainya secara tepat. Pertanyaan apakah maksud Tuhan di balik wabah Corona mendorong gereja untuk berintrospeksi dan segera mengambil sikap yang benar dalam kehidupannya. Salah satunya adalah bagaimana praksis pendidikan agama Kristen dilakukan oleh gereja-gereja. Oleh sebab itu penting untuk kembali melihat pemahaman mengenai hakikat dan tujuan pendidikan agama Kristen.

\section{Hakikat dan Tujuan Pendidikan Agama Kristen}

Pendidikan sejatinya merupakan usaha sadar dan terencana untuk mewujudkan suasana belajar dan proses pembelajaran agar peserta didik secara aktif mengembangkan potensi dirinya sehingga memiliki kekuatan spiritual keagamaan, pengendalian diri, kepribadian, kecerdasan, akhlak mulia, serta keterampilan yang diperlukan dirinya dan masyarakat ${ }^{3}$. Dengan meminjam penjelasan dari Sidjabat, pendidikan dapat dikatakan berasal dari dua kata Latin yakni educare yang berarti merawat, memperlengkapi dengan

2 Agus Warsudi, "Virus Corona Mewabah, Jumlah Orang Dengan Gangguan Jiwa Di Jabar Meningkat," Sindonews.Com (Bandung, April 17, 2020), https://jabar.sindonews.com/read/3309/701/viruscorona-mewabah-jumlah-orang-dengan-gangguan-jiwa-di-jabar-meningkat-1587121477.

${ }^{3}$ T Umar and S. L. La Sulo, Pengantar Pendidikan (Jakarta: Rineka Cipta, 2005). 
gizi agar sehat dan kuat, dan educere yang berarti membimbing ke luar maka dapat disimpulkan bahwa pendidikan merupakan sebuah upaya sadar dan sengaja untuk memperlengkapi seseorang atau sekelompok orang, guna membimbing ke luar dari suatu tahapan — keadaan — hidup ke suatu tahapan yang lebih baik ${ }^{4}$. Jadi dari pendapat ini dapat dikatakan bahwa sebenarnya pendidikan mempunyai sebuah misi transformasi. Berupaya mengubah kehidupan seseorang menjadi lebih baik, membuat orang tidak tahu menjadi tahu, untuk mengenalkan kepada orang sebuah dimensi pemikiran baru yang dapat mentransformasi kehidupan.

Setelah memahami arti pendidikan secara umum maka perlu dibahas pula pengertian Pendidikan Agama Kristen. Dalam ruang lingkup pendidikan, sudah tidak asing lagi ketika mendengar kata Pendidikan Kristen atau Pengajaran Kristen, Pendidikan Agama atau Pengajaran Agama. Istilah-istilah tersebut sesungguhnya mempunyai arti yang berbeda. Pendidikan Kristen biasanya dipergunakan untuk pengajaran di sekolah-sekolah Kristen, baik sekolah rakyat maupun sekolah lanjutan yang masih dijalankan oleh gereja atau organisasi Kristen. Jadi nama ini menunjuk kepada pengajaran biasa yang diberikan dengan suasana Kristen ${ }^{5}$. Sedangkan istilah Pendidikan—-pengajaran-Agama mempunyai cakupan yang sangat luas. Misalnya saja di Indonesia mayoritas agama adalah Islam jadi mungkin pikiran orang terus terarah kepada pengajaran agama Islam jika hanya mengatakan Pendidikan Agama saja. Oleh sebab itu istilah yang lebih khusus adalah Pendidikan Kristen (Christian Education) atau dapat juga Pendidikan Agama Kristen (Christian Religious Education) ${ }^{6}$.

Robet W. Pazmino sebagaimana dikutip oleh Sidjabat mengungkapkan bahwa Pendidikan Kristen (Christian Education) merupakan usaha bersahaja dan sistematis, ditopang oleh upaya rohani dan manusiawi untuk mentransmisikan pengetahuan, nilainilai, sikap-sikap, keterampilan-keterampilan, dan tingkah laku yang sesuai dengan iman Kristen; mengupayakan perubahan, pembaharuan dan reformasi pribadi-pribadi, kelompok bahkan struktur oleh kuasa Roh Kudus sehingga peserta didik hidup sesuai dengan kehendak Allah sebagaimana dinyatakan oleh Alkitab terutama dalam Yesus Kristus ${ }^{7}$. Jadi dari pernyataan ini dapat disimpulkan bahwa fokus Pendidikan Agama Kristen itu adalah mengenai pembaharuan hidup seseorang supaya sejalan dengan kehendak Kristus dengan

\footnotetext{
${ }^{4}$ B.S Sidjabat, Strategi Pendidikan Kristen (Yogyakarta: Andi Offset, 1999), 8.

${ }^{5}$ E. G Homrighausen and I. H. Enklaar, Pendidikan Agama Kristen (Jakarta: BPK Gunung Mulia, 2015), 19.

${ }^{6}$ Ibid., 19-20.

${ }^{7}$ Sidjabat, Strategi Pendidikan Kristen, 10.
} 
berlandaskan firman Tuhan yang tertuang dalam Alkitab. Dengan kata lain, Pendidikan Agama Kristen dapat disebut sebagai pendidikan berbasis Alkitab.

Homrighausen dan Enklaar merumuskan tujuan Pendidikan Agama Kristen sebagai berikut $^{8}$ :

1. Supaya ia (murid/ peserta didik) mengenal ajaran-ajaran asasi dari agama Kristen

2. Supaya ia bekerja sama dengan Allah untuk mendatangkan kerajaan-Nya sambil membaktikan diri kepada penguasanya

3. Supaya ia mengambil bagian secara efektif dalam jemaat setempat

4. Supaya ia menumbuhkan keyakinan akan persekutuan rohani semua orang percaya

5. Supaya ia mengambil bagian dalam kebaktian suci, baik dalam rumah tangga ataupun gereja

6. Supaya ia dapat bersaksi dengan perkataan maupun perbuatan, sambil menaruh perhatian terhadap usaha pekabaran Injil dari Gereja

7. Supaya ia hidup sebagai orang Kristen yang dalam segala-galanya bertanggung jawab terhadap Tuhannya.

Selain itu, tujuan Pendidikan Agama Kristen adalah membawa manusia kembali kepada sang pencipta agar dapat hidup benar dan bersekutu kembali kepada Allah ${ }^{9}$. Proses Pendidikan Agama Kristen dimulai dari "kelahiran baru" (2Kor. 5:17) agar manusia dapat mengalami perkembangan dan kemajuan menurut kehendak Allah tanpa mengabaikan kehendak bebas manusia. Selain itu, Pendidikan Agama Kristen juga berupaya atau bertujuan untuk mendampingi dan memperlengkapi manusia agar mengalami pertumbuhan imannya secara utuh atau mengalami perkembangan secara fisik, jiwa, dan $\operatorname{roh}^{10}$.

Pendidikan Agama Kristen seharusnya juga berupaya untuk menyatakan Injil itu dalam hidup pribadi dan sosial. Pendidikan Agama Kristen harus berupaya untuk membimbing murid bertumbuh dalam hidup pribadinya itu dalam hubungan-hubungannya dengan orang lain, membimbing siswa agar dapat mengenal panggilan Allah serta menjawabnya dengan pembaktian hidupnya. Pendidikan Agama Kristen harus mendorong mereka untuk menyatakan imannya dalam lingkungan keluarga dan merasakan tanggung jawabnya terhadap orang lain dan melakukan kewajibannya dalam usaha membentuk tata

${ }^{8}$ Homrighausen and Enklaar, Pendidikan Agama Kristen, 37.

${ }^{9}$ Slamet Santoso, "Resensi Buku Pendidikan Kristen Konteks Sekolah: 12 Pesan Untuk Guru Dan Pengelola," Jurnal Abdiel: Khazanah Pemikiran Teologi, Pendidikan Agama Kristen, dan Musik Gereja 3, no. 1 (2019): 77-79, https://doi.org/10.37368/ja.v3i1.38.

${ }^{10}$ Ibid. 
sosial yang lebih baik ${ }^{11}$. Dapat disimpulkan bahwa Pendikan Agama Kristen tidak hanya berfokus kepada pembentukan iman saja, tetapi juga harus dapat membuat seseorang mempunyai jiwa sosial yang baik, mempunyai kepedulian sosial.

Hal itu menarik untuk direnungkan, apalagi melalui Pendidikan Agama Kristen ada mandat untuk menjadikan semua bangsa menjadi murid-Nya dan implementasinya adalah dengan mengajar. Namun demikian, bukan hanya dengan mengajar saja untuk mengimplementasikan tugas yang diberikan oleh Yesus, namun harus dibarengi dengan jiwa sosial yang baik. Hal ini sejalan dengan pemikiran Groome yang menyatakan bahwa salah satu tujuan dari Pendidikan Agama Kristen adalah kebebasan manusia sebagai perwujudan iman Kristen. Kebebasan adalah ekspresi iman yang merupakan tanggapan atas karya Allah yang membebaskan manusia di dalam Yesus Kristus ${ }^{12}$. Tujuan ini mencakup dimensi mental dan spiritual manusia, baik secara pribadi maupun komunal, serta memiliki dimensi sosial dan politis karena mengarahkan seseorang untuk hidup menjadi warga negara yang baik $^{13}$. Semuanya itu terangkum dalam tujuan besar dari Pendidikan Agama Kristen yang disebutnya dengan istilah metapurpose yakni Kerajaan Allah $^{14}$.

Berkaitan dengan istilah Kerajaan Allah, Groome mengubah istilah Kingdom of God yang digunakannya dalam Christian Religious Education menjadi Reign of God dalam bukunya yang berjudul Sharing Faith. Perubahan ini merupakan respon terhadap kritik kaum feminis yang menganggap istilah Kingdom of God memiliki konotasi maskulin ${ }^{15}$. Artinya, dalam Pendidikan Agama Kristen, kebebasan sebagai perwujudan iman Kristen menyertakan juga pemahaman adanya kesetaraan antara laki-laki dan perempuan.

Berdasarkan penjelasan mengenai hakikat dan tujuan Pendidikan Agama Kristen sebagaimana dijelaskan, hal yang menonjol adalah adanya gagasan mengenai upaya pembebasan dari masalah-masalah nyata di dunia ini sebagai ekspresi iman berdasarkan firman Tuhan yang terkandung dalam Alkitab. Oleh sebab itu penting untuk melihat bagaimana gereja-gereja mula-mula memberikan pengajaran berdasarkan persoalan yang tengah dihadapi sebagaimana tercermin dalam teks-teks Alkitab. Salah satunya adalah nasihat-nasihat rasul Paulus kepada jemaat-jemaat di Galatia yang tengah menghadapi

${ }^{11}$ Homrighausen and Enklaar, Pendidikan Agama Kristen, 37.

12 T. H Groome, Sharing Faith: A Comprehensive Approach to Religious Education \& Pastoral Ministry (San Fransisco: Harper \& Row, 1991), 21.

${ }_{13}$ Ibid., 11-12.

14 Ibid., 14.

${ }^{15}$ Ibid., 14-17. 
persoalan serius yakni adanya gangguan pengajaran yang disebutnya dengan "injil lain". Bagaimana pengajaran yang dilakukan oleh Paulus bagi jemaat-jemaat di Galatia pada waktu itu?

\section{Bertolong-tolonganlah Menanggung Bebanmu}

Salah satu pengajaran Paulus kepada jemaat-jemaat yang tengah menghadapi kesulitan serius tertulis dalam Galatia 6:2, "Bertolong-tolonganlah menanggung bebanmu! Demikianlah kamu memenuhi hukum Kristus." Nasihat ini disampaikan kepada jemaatjemaat di Galatia yang pada saat itu menghadapi beberapa persoalan. Salah satu persoalan yang dihadapi oleh jemaat-jemaat di Galatia terekam melalui pernyataan keras Paulus dalam Galatia 1:6, “Aku heran, bahwa kamu begitu lekas berbalik dari pada Dia, yang oleh kasih karunia Kristus telah memanggil kamu, dan mengikuti suatu injil lain”.

Paulus tampaknya geram dengan masuknya pengajaran yang dibawa oleh orangorang yang menekankan tradisi Yahudi sebagai keutamaan dalam kehidupan gereja yang dirintisnya. Sikap keras Paulus ini ditegaskan kembali ketika menyinggung sosok Petrus yang disebutnya Kefas, juga Barnabas; yang keduanya disebut bersikap munafik (Gal. 2:11-13). Sikap keduanya dianggap menyimpang dari Injil yang telah diberitakan oleh Paulus, yang oleh banyak ahli dirumuskan dalam Galatia 3:28, "Dalam hal ini tidak ada orang Yahudi atau orang Yunani, tidak ada hamba atau orang merdeka, tidak ada laki-laki atau perempuan, karena kamu semua adalah satu di dalam Kristus Yesus.” Inilah injil yang telah diwartakan oleh Paulus, tetapi yang kemudian terancam dikacaukan dengan masuknya injil lain, yang memuat ajaran tentang keutamaan tradisi Yahudi di atas tradisi bangsa-bangsa lainnya. Sikap orang-orang yang menekankan keutamaan tradisi Yahudi ini sama dengan sikap orang-orang Romawi yang oleh Lopez disebut sebagai ideologi imperialis. Dalam ideologi ini seseorang menganggap bangsanya lebih unggul dibanding yang lain, serta berhak menilai dan memperlakukan bangsa-bangsa lain menurut ukuran dan kepentingan yang dimiliki oleh bangsanya ${ }^{16}$. Lopez sebagaimana dijelaskan oleh Nataniel melanjutkan, Paulus tidak lagi memiliki pandangan demikian setelah ia bertobat. Paulus menanggalkan ideologi imperialis itu dan menggantikannya dengan menempatkan diri sebagai bagian dari orang-orang terjajah yang memperjuangkan penghapusan

${ }^{16}$ D. C Lopez, Apostle to the Conquered: Reimagining Paul's Mission (Minneapolis: Fortress Press, 2010), 121. 
imperialisme ${ }^{17}$. Sikap ini dinyatakan ketika ia menempatkan diri sebagai seorang perempuan dalam keadaan sakit bersalin sebagaimana ditulis dalam Galatia 4:19, dan dalam Galatia 4:27 yang menyerukan suka cita bagi perempuan-perempuan mandul dan tidak pernah merasakan persalinan. Simbol-simbol feminin yang dinyatakan oleh Paulus merupakan bentuk solidaritas terhadap bangsa-bangsa jajahan sekaligus seruan untuk bersatu bagi semua bangsa sebagaimana dinyatakan dalam Galatia 3:28. Dengan memperhatikan berbagai produk kebudayaan masyarakat di bawah imperium Romawi maka dapat terlihat jelas bahwa simbol-simbol feminin merepresentasikan keberadaan bangsa-bangsa jajahan yang diperlawankan dengan penguasa Romawi yang ditampilkan dengan simbol-simbol maskulin ${ }^{18}$. Dalam hal ini, Paulus mencoba untuk memberi kesadaran bagi semua jemaatnya, baik yang berlatar belakang Yahudi maupun bukan Yahudi bahwa ada musuh bersama yang tengah mereka hadapi, yakni ideologi imperialis yang menguasai pemikiran dan sikap hidup masyarakat pada waktu itu.

Upaya dan seruan Paulus sebagaimana tertulis dalam Galatia 3:28 tentu saja menuai penolakan dan perlawanan. Apa yang dilakukan oleh Paulus dapat dianggap sebagai sesuatu yang naif dan tidak masuk akal bagi masyarakat pada waktu itu. Pendirian Paulus yang dianggap naif ini sejalan dengan pilihannya menempatkan salib Kristus sebagai simbol keutamaan orang-orang Kristen. Bagi orang-orang Yahudi, salib itu dianggap sebagai batu sandungan, sedangkan oleh orang-orang Yunani dilihat sebagai sebuah kebodohan seperti diakuinya dalam 1 Korintus 1: 23. Di situ Paulus berkata, “ ... tetapi kami memberitakan Kristus yang disalibkan: untuk orang-orang Yahudi suatu batu sandungan dan untuk orang-orang bukan Yahudi suatu kebodohan.”

Di tengah situasi sulit dan penuh perlawanan terhadap dirinya, Paulus konsisten mengajak jemaat-jemaat di Galatia untuk menghadapi ideologi imperialis sebagai musuh bersama. Di antaranya adalah dengan saling memberikan pertolongan satu sama lain. Dalam Galatia 6:2 tertulis, "Bertolong-tolonganlah menanggung bebanmu! Demikianlah kamu memenuhi hukum Kristus." Kata "beban” yang dipakai adalah ta barē yang merupakan bentuk neuter jamak dari kata baros. Kata-kata ini merujuk kepada kesulitankesulitan yang membuat seseorang atau sekelompok orang harus bekerja keras dan mengalami tekanan batin seperti dalam Matius 20:12, Kisah Para Rasul 15:28, 2 Korintus 4:17, dan Wahyu 2:24. Di ayat-ayat itu, kata baros digunakan untuk menggambarkan

\footnotetext{
${ }^{17}$ Demianus Nataniel, "Paulus Dalam Konflik Antarumat Beragama: Membaca Konflik Di Maluku Utara Berdasarkan Sikap Nasionalisme Paulus," GEMA TEOLOGIKA: Jurnal Teologi Kontekstual \& Filsafat Keilahian 4, no. 2 (2019).

${ }^{18}$ Lopez, Apostle to the Conquered: Reimagining Paul's Mission, 36.
} 
berbagai kesulitan yaitu pekerjaan fisik yang menguras tenaga (Mat. 20:12), aturan-aturan keagamaan (Kis. 15:28), dan tekanan-tekanan sosial serta penganiayaan fisik yang dialami oleh orang-orang Kristen dalam menyatakan eksistensinya (2Kor. 4:17; Why. 2:24). Ideologi imperialis yang dilawan bersama-sama tampaknya memang membutuhkan ketahanan fisik dan mental. Itu tidak dapat dilakukan sendiri-sendiri, perlu kerja sama, dan saling membantu satu sama lain.

Nasihat agar jemaat-jemaat saling menolong tidak semata-mata untuk diri mereka sendiri. Konsep keselamatan yang dimiliki oleh Paulus tidak semata-mata bersifat pribadi dan rohani, serta berhubungan dengan kehidupan setelah kematian. Nasihat-nasihat Paulus dalam surat-suratnya yang berhubungan dengan tema keselamatan menunjukkan bahwa Paulus berusaha mengarahkan orang-orang Kristen untuk benar-benar melakukan perbuatan-perbuatan baik sebagai unsur yang sangat penting dalam menerima keselamatan di dunia saat $\mathrm{ini}^{19}$, termasuk ketika ia berbicara tentang akhir zaman. Nasihat-nasihatnya yang berhubungan dengan akhir zaman disampaikannya bukan agar jemaat-jemaat melarikan diri dari tanggung jawab untuk memperbaharui kehidupan sosial masyarakatnya atau lebih asyik dengan dirinya sendiri, tetapi supaya dengan bersungguh-sungguh mereka turut memulihkan segala kerusakan yang ada di tengah-tengah masyarakat supaya pada saatnya gereja tidak kedapatan bercacat dan bercela ${ }^{20}$.

Selain itu juga diperlukan adanya orang-orang yang dapat dijadikan contoh atau teladan. Dalam konteks masyarakat di Indonesia, kebutuhan orang-orang ini tidak dapat dipungkiri mengingat budaya patron-client sangat terasa. Para pemimpin diharapkan dapat menjadi contoh dan teladan. Dalam konteks gereja mula-mula, Paulus telah menunjukkan hal tersebut. Sebagai seorang pemimpin dia berusaha untuk menunjukkan konsistensinya dalam mengajarkan Injil yang disebutnya langsung berasal dari Kristus sendiri kepada jemaat-jemaat yang dibinanya seperti pernyataannya dalam Galatia 1:12, "Karena aku bukan menerimanya dari manusia, dan bukan manusia yang mengajarkannya kepadaku, tetapi aku menerimanya oleh pernyataan Yesus Kristus.” Konsistensi Paulus ini mencerminkan sikap seorang pemimpin yang berani mengambil risiko, bertanggung jawab dan memasuki situasi yang rentan terhadap penolakan dan kegagalan ${ }^{21}$. Konsistensinya

19 Demianus Nataniel, "Parousia, Pembenaran Allah, Dan Kebangkitan Orang Mati: PerbuatanPerbuatan Baik Dalam Meraih Keselamatan Menurut Surat-Surat Paulus," Jurnal Abdiel: Khazanah Pemikiran Teologi, Pendidikan Agama Kristen, dan Musik Gereja 2, no. 1 (2018): 33-47, https://doi.org/10.37368/ja.v2i1.59.

${ }^{20}$ Ibid., 46.

${ }^{21}$ Dwi Atni Setyowati, "Konflik Kepemimpinan Dalam Pekabaran Injil: Sebuah Pemaknaan Terhadap Perselisihan Paulus Dan Barnabas Dalam Kisah Para Rasul 15:35-41," Jurnal Abdiel: Khazanah Pemikiran 
juga terlihat ketika Paulus akhirnya mengambil rute dan arah pekabaran Injil yang berbeda dengan Barnabas. Meskipun ada penafsir yang melihat keputusan Paulus dan Barnabas sebagai sesuatu yang menyedihkan ${ }^{22}$, tetapi Kisah Para Rasul sendiri melihat bahwa perbedaan arah perjalanan dalam pekabaran Injil yang mereka tempuh dilihat secara positif sebagai sumbangsih dalam memperluas wilayah pekabaran Injil ${ }^{23}$.

Dalam kapasitasnya sebagai seorang pemimpin, Paulus juga mengajak jemaat untuk tidak menyerah pada keadaan. Sebaliknya memanfaatkan situasi sulit sebagai sebuah cara untuk menghasilkan sesuatu yang bernilai. Di tengah tantangan menghadapi orangorang Kristen yang berlatar belakang Yahudi yang dikuasai ideologi imperialis, Paulus berusaha menawarkan nilai-nilai baru sebagai ekspresi iman di dalam Yesus Kristus. Anjuran bertolong-tolonganlah dalam menanggung beban juga dapat dilihat sebagai ekspresi iman di tengah tantangan berat. Apa yang dilakukan oleh Paulus ini memang sangat khas. Keterampilannya dalam beretorika membuat Paulus dapat memanfaatkan halhal yang dianggap oleh masyarakat umum sebagai yang buruk dan rendah, menjadi sesuatu yang bernilai. Mulai dari sakit yang diderita hingga penolakan terhadap dirinya dari kelompok tertentu di Korintus, semuanya dijadikan alat untuk menyampaikan gagasangagasannya yang progresif. Inilah sosok pemimpin yang dibutuhkan oleh masyarakat dalam menghadapi musuh bersama, seperti wabah virus Corona yang melanda dunia saat ini. Pertanyaannya adalah bagaimana ini diimplementasikan dalam praxis Pendidikan Agama Kristen di tengah masyarakat pluralis seperti di Indonesia, yang tengah mengalami wabah seperti pandemi virus Corona?

\section{Dialog yang Membebaskan dan Menyejahterakan}

Teori Pendidikan Agama Kristen dapat berjalan secara dinamis tidak terlepas dari sebuah perjalanan dan refleksi dalam dialog dengan yang lainnya. Artinya bahwa teori pendidikan tidak dapat hadir dalam ruang hampa, tetapi muncul dari pengalaman hidup manusia dalam konteksnya ${ }^{24}$. Menurut Christiani sebagaimana dikutip oleh Slamet Santoso, Pendidikan Kristiani bukan sekedar kegiatan meneruskan dogma dari waktu ke waktu dan menghafalkannya, melainkan mempertemukan ajaran-ajaran gereja itu dengan

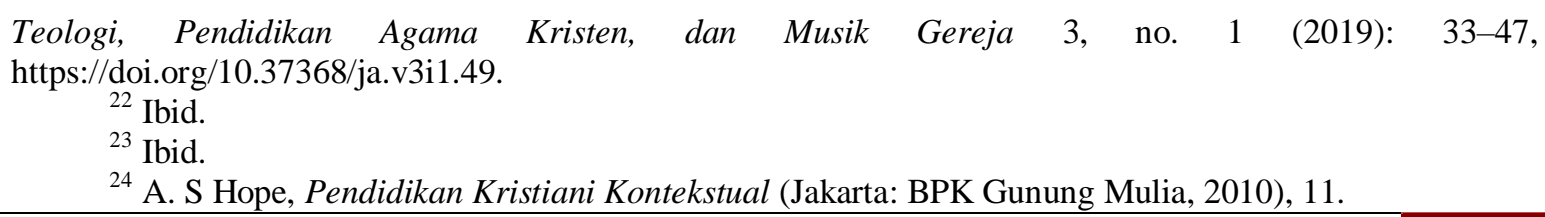


kehidupan masa kini dalam percakapan yang mengarah ke masa depan yang adil dan penuh pengharapan ${ }^{25}$.

Menurut Wilkerson sebagaimana yang dikutip juga oleh Slamet Santoso, tujuan Pendidikan Agama Kristen yang berhubungan dengan multikultural secara autentik terdiri dari beberapa hal yaitu ${ }^{26}$ :

1. Gereja perlu memahami dan menyadari bahwa keberadaanya di dunia memiliki anggota jemaat yang terdiri dari multi etnis, multi bahasa, dll.

2. Gereja perlu membangun sikap positif terhadap keberagaman yang dapat memperkaya iman Kristen dan dapat membawa keutuhan atau kesatuan jemaat, bukan sebaliknya sebagai ancaman terhadap iman Kristen.

3. Gereja perlu memiliki sikap menghargai, menilai budayanya sendiri, sehingga gereja dapat menghargai budaya lain.

4. Gereja atau orang Kristen yang menghargai perbedaan dengan pengalaman hidup kekristenannya perlu diwujudkan dalam Pendidikan kristiani.

Pandangan dari Wilkerson dalam menyikapi pendidikan multikultural tampaknya lebih kepada mengusahakan adanya perjuangan hak yang setara dalam pendidikan. Dalam hal ini tampaknya baik untuk melihat pandangan Antone Hope. Untuk Pendidikan Agama Kristen, Hope lebih menekankan pluralisme dengan adanya sikap toleransi, menerima, dan menghargai perbedaan agama ${ }^{27}$. Pendidikan Agama Kristen melalui guru atau pengajar sejatinya harus dapat mengarahkan untuk dapat hidup berdampingan dengan agama lain, dapat memupuk jiwa toleransi, dapat membangun hubungan yang baik, dan saling bekerja sama untuk menciptakan suasana hidup yang damai.

Salah satu cara supaya Pendidikan Agama Kristen tetap eksis adalah dengan mengupayakan agar dalam Pendidikan Agama Kristen tertanam nilai-nilai toleransi, saling menghargai perbedaan. Cara yang lain agar dapat hidup berdampingan adalah dengan berjumpa dan berdialog. Dialog yang dimaksud adalah dialog yang sungguh-sungguh mendorong dan memberi peluang semua pihak untuk melakukan perubahan ke arah yang lebih baik. Masalah terbesar dalam dalam konteks pluralisme adalah adanya konsep mayoritas dan minoritas. Dalam ide Negara kesatuan, kelompok mayoritas yang dijiwai oleh fanatisme agama yang membuatnya merasa superior akan menyebabkan terjadinya

${ }^{25}$ Slamet Santoso, "Tinjauan Kritis Terhadap Pendidikan Agama Multikultural Barbara Wilkerson," Jurnal Abdiel: Khazanah Pemikiran Teologi, Pendidikan Agama Kristen, dan Musik Gereja 2, no. 2 (2018): 56-71, https://doi.org/10.37368/ja.v2i2.32.

${ }^{26}$ Ibid.

${ }^{27}$ Hope, Pendidikan Kristiani Kontekstual, 47. 
religious totality. Sedangkan golongan minoritas cenderung enggan terhadap mayoritas. Situasi ini dapat menjadi masalah ketika mayoritas berusaha menjadi penentu nasib $\operatorname{minoritas}^{28}$. Jika ini terjadi pasti akan menimbulkan permasalahan yang sangat rumit karena pasti akan ada pihak yang dikecewakan dan mengecewakan, memuaskan dan dipuaskan.

Terlepas dari itu semua, harus dimengerti bahwa manusia adalah makhluk "monodualis" artinya manusia itu adalah makhluk pribadi sekaligus makhluk sosial. Manusia sebagai pesona atau pribadi adalah makhluk yang dapat berkata "aku" dengan sadar dan insyaf. Kepribadiannya tersebut didasarkan pada kerohaniannya. Mengingat manusia bersifat monodualis, hubungan antar sesama dapat dirumuskan sebagai hubungan antara "aku" dan "engkau" yang sederajat sesuai dengan dan martabat manusia itu sendiri. Aku dan engkau dalam perjumpaan dan dalam ikatan kebersamaan, kemudian menjadi "kita" 29 . Jadi keberadaan manusia adalah bersama dalam perjumpaan dengan sesamanya. Oleh sebab itu, manusia tidak dapat hidup sendiri atau menyendiri tanpa berhubungan dengan orang lain sebagai sesamanya. Manusia bermasyarakat, sementara masyarakat akan terbina apabila setiap persona (warga masyarakat) saling berhubungan dengan persona yang lain dan mengadakan semacam kontrak hidup bersama ${ }^{30}$.

Masih berkaitan dengan pentingnya dialog, Ronald H. Cram sebagaimana dikutip oleh Nataniel mengingatkan bahwa kesadaran mengenai konteks pluralisme tidak membuahkan hasil apapun jika hanya sampai pada taraf kesadaran semata ${ }^{31}$. Perlu ada sesuatu yang harus dilakukan berkenaan dengan konteks ini mengingat kenyataan tersebut telah menghasilkan berbagai persoalan, termasuk konflik yang berdarah-darah ${ }^{32}$. Cram dalam hal ini mengajukan sebuah model pendidikan agama yang melampaui konsep toleransi dalam konteks pluralisme ${ }^{33}$. Ia mengusulkan pendidikan agama dalam bentuk dialog yang bersifat radikal, yang didasarkan pada kesanggrahan (hospitality), yang digambarkan sebagai tarian yang terdiri dari gerakan harmonis dari empati, kepedulian, dan persahabatan ${ }^{34}$. Menurutnya, dialog radikal itu sesuai dengan apa yang digambarkan 11.

${ }^{28}$ B. S Drie, Pendidikan Agama Kristen Untuk Perguruan Tinggi (Yogyakarta: Andi Offset, 2008),

${ }^{29}$ Ibid., 12.

30 Ibid.

31 Demianus Nataniel, "Soteriologi Menurut Paulus Sebagai Dasar Tradisi Bagi Pelaksanaan Pendidikan Agama Dalam Konteks Pluralisme Di Indonesia," Jurnal Abdiel: Khazanah Pemikiran Teologi, Pendidikan Agama Kristen, dan Musik Gereja 3, no. 1 (2019): 60-76, https://doi.org/10.37368/ja.v3i1.45.

32 Ibid.

33 Ibid.

34 Ibid. 
dalam perjumpaan antara Yesus dengan perempuan Kanaan (Mat. 15:21-28) ${ }^{35}$. Dengan demikian Pendidikan agama Kristen dalam konteks pluralisme seharusnya dapat mengajak semua orang untuk mau menerima keberagaman yang ada. Dengan kata lain pendidikan agama dilakukan juga dalam bentuk mensosialisasikan nilai-nilai yang berkembang di tengah masyarakat majemuk sehingga kepelbagaian menjadi sebuah kesadaran yang menyatu dalam diri setiap orang Kristen ${ }^{36}$. Pertanyaanya adalah nilai keutamaan apa yang ada di tengah masyarakat Indonesia, yang dapat dipakai sebagai bentuk dialog radikal sebagaimana yang diusulkan oleh Cram?

\section{Gotong Royong sebagai Dialog yang Membebaskan dan Menyejahterakan}

Salah satu nilai keutamaan yang terkandung dalam filosofi bangsa Indonesia adalah "gotong royong". Nilai keutamaan yang sering disebut sebagai perasan lima sila dari Pancasila dan keunggulan dari budaya bangsa Indonesia ini sangat terasa di tengah situasi mengatasi wabah Covid-19. Di banyak tempat di berbagai wilayah Indonesia tampak inisiatif warga bergotong royong dalam mengatasi penyebaran virus Corona. Mulai dari swadaya masyarakat dalam membangun posko-posko pemutus penyebaran virus Corona hingga inisiatif lembaga-lembaga sosial masyarakat, institusi pendidikan, bahkan perusahaan untuk menggalang dana guna mencegah penyebaran virus tersebut. Oleh sebab itu tidak mengherankan jika dari presiden hingga aparat desa menyerukan masyarakat Indonesia untuk bergotong royong bagi penyebaran Covid-19. Dengan kata lain, gotong royong dapat dijadikan salah satu nilai keutamaan yang dimiliki oleh bangsa Indonesia, yang dapat dijadikan jembatan dalam mengatasi kepelbagaian di tengah masyarakat Indonesia. Gotong royong dalam hal ini dapat dijadikan nilai keutamaan dari budaya bangsa Indonesia sebagai model dialog radikal yang melampaui toleransi sebagaimana yang dipikirkan oleh Cram. Lebih dari itu nilai gotong royong ini juga dapat ditemukan dalam banyak tradisi keagamaan sebagaimana juga dalam tradisi Kristen seperti nasihat Paulus dalam Galatia 6:2.

Dalam konteks Pendidikan Agama Kristen di tengah masyarakat di Indonesia yang majemuk, konsep gotong royong ini bukan hanya dapat menjadi bagian dari materi pembelajaran, tetapi juga menjadi wujud nyata dalam relasi para pelaku pendidikan, termasuk relasi guru dan murid. Relasi ini sesuai dengan pandangan Groome yang

35 Ibid.

36 Ibid. 
mengusung paradigma ziarah dalam Pendidikan Agama Kristen ${ }^{37}$. Berkaitan dengan relasi diantara para pelaku pendidikan, semuanya dipahami sebagai musafir. Konsekuensinya, guru dan murid berada dalam relasi kemitraan yang bersifat dialogis, saling melengkapi, dan membebaskan ${ }^{38}$. Guru dan murid sama-sama dipahami sebagai orang yang sedang belajar, meskipun masing-masing harus menyadari peran dan fungsinya masing-masing ${ }^{39}$. Situasi ini tergambar antara lain ketika dosen, mahasiswa, dan karyawan STT Abdiel turut serta membantu pemerintah dalam menghambat penyebaran virus Corona. Mereka bersama-sama belajar membuat face shield dan hand sanitizer untuk dibagikan kepada masyarakat. Pada saat membagikan face shield dan hand sanitizer, kepelbagaian yang sering menjadi pemisah diruntuhkan. Dosen dan mahasiswa STT Abdiel yang beragama Kristen tidak membedakan siapa saja yang akan menerima hasil karya mereka, demikian juga dengan masyarakat yang menerimanya. Semuanya dapat dilihat sebagai para musafir yang berjalan bersama, yang membutuhkan kesehatan dan kesejahteraan.

Berangkat dari nasihat Paulus kepada jemaat-jemaat di Galatia yang mencerminkan keterampilannya dalam memanfaatkan situasi sulit menjadi sarana pembelajaran yang efektif, maka penting untuk melihat wabah virus Corona secara positif dalam terang kasih Tuhan. Di satu sisi wabah ini membuat kematian begitu dekat dengan siapapun. Namun demikian, di sisi lain situasi ini membuat masyarakat semakin menyadari betapa berharganya hidup yang diberikan Tuhan, sekaligus juga yang rentan untuk diambil-Nya kembali. Kedisiplinan dalam menjaga kesehatan diri dan lingkungan mulai diperhatikan. Gerakan cuci tangan dan penggunaan masker menunjukkan sikap pro kehidupan dan penghargaan terhadap tubuh yang Allah berikan.

Ancaman Corona juga mengakibatkan masalah ekonomi, yang pada gilirannya membuat kecemasan meningkat dan mengganggu kondisi dan kesehatan mental seseorang. Namun demikian, situasi ini membuat masyarakat berusaha belajar hidup hemat dan tidak menghambur-hamburkan uang. Belum lagi ada upaya saling membantu di antara sesama warga masyarakat. Penggalangan dana oleh pribadi maupun kelompok masyarakat menunjukkan adanya kepedulian satu terhadap yang lain. Mulai dari sumbangan dalam bentuk barang-barang kebutuhan pokok hingga alat-alat kesehatan. Bukan berapa besar dan berapa banyak yang mungkin dapat dikumpulkan dan disumbangkan seseorang atau

${ }^{37}$ T. H Groome, Christian Religious Education: Sharing Our Story and Vision (San Fransisco: Harper \& Row, 1980), 12-17.

38 Demianus Nataniel, "Paradigma Ziarah Dalam Penafsiran Alkitab," Jurnal Abdiel: Khazanah Pemikiran Teologi, Pendidikan Agama Kristen, dan Musik Gereja 2, no. 2 (2018): 43-55, https://doi.org/10.37368/ja.v2i2.50.

39 Ibid. 
sekelompok orang kepada sesamanya, tetapi kepedulian di antara sesama manusia yang patut diapresiasi. Dalam hal ini tentu tidak dapat ditutupi juga kemungkinan bahwa ada orang-orang yang memanfaatan situasi untuk meraup keuntungan di tengah kesusahan yang dialami oleh orang lain.

Wabah Corona juga membuat kalang kabut dunia pendidikan. Kebiasaan belajar di ruang-ruang kelas terganggu dengan wabah ini. Namun demikian situasi ini justru membuat lembaga-lembaga yang menyelenggarakan pendidikan bergerak lebih maju dalam memanfaatkan perkembangan teknologi informasi dan komunikasi. Demikian halnya dalam kehidupan beragama. Pola-pola peribadatan yang menekankan aspek ritual secara bersama-sama ditantang dengan kondisi yang membuat masyarakat sulit untuk berkumpul bersama-sama di sebuah tempat. Namun demikian, situasi inipun menjadikan masyarakat mulai berpikir logis dan rasional dalam menjalankan aktivitas keagamaannya. Dalam konteks kehidupan bergereja misalnya, masyarakat mulai merumuskan kembali konsep ekklesiologi yang diyakininya selama ini. Apakah tugas panggilan gereja yang berhubungan dengan persekutuan harus selalu dilakukan dengan tatap muka atau tidak? Situasi ini tentu membuat gereja menjadi lebih kritis dan bertanggung jawab dalam menjalankan agamanya, termasuk melihat sisi-sisi penting dan terdalam dari agama-agama yakni menempatkan manusia dan seluruh ciptaan Tuhan dengan sangat berharga, dalam suasana dan ikatan yang saling memperdulikan satu dengan yang lainnya.

\section{Kesimpulan}

Wabah virus Corona memang telah menimbulkan berbagai masalah kemanusiaan. Namun demikian ada beberapa pengaruh positif yang dirasakan dalam kehidupan manusia. Kepedulian terhadap kesehatan dan sikap pro terhadap kehidupan semakin terasa. Ketergantungan seseorang terhadap yang lain semakin kuat menyusul kebijakan untuk menjaga jarak di antara sesama manusia dalam interaksinya. Situasi ini juga membuat kreativitas manusia tertantang untuk dapat mengatasi berbagai kendala dalam menjalani kehidupan, sekaligus kreativitas dalam hal saling menolong. Sebagaimana Paulus yang telah menunjukkan keterampilannya dalam memanfaatkan situasi sulit menjadi sarana pengajaran yang efektif. Gereja juga hendaknya semakin kreatif dalam melaksanakan tugas panggilannya, termasuk dalam praxis pendidikan agama Kristen. Semoga wabah virus Corona ini semakin membuat manusia memperlakukan sesama ciptaan Tuhan lainnya sungguh-sungguh bernilai di hadapan dirinya dan di hadapan Tuhan. 


\section{Kepustakaan}

Amirullah. "Survei SMRC: 77 Persen Publik Merasa Covid-19 Ancam Penghasilan." Tempo. Jakarta, April 17, 2020. https://nasional.tempo.co/read/1341315/jokowiminta-pengendalian-covid-19-di-pulau-jawa-makin-efektif.

Drie, B. S. Pendidikan Agama Kristen Untuk Perguruan Tinggi. Yogyakarta: Andi Offset, 2008.

Groome, T. H. Christian Religious Education: Sharing Our Story and Vision. San Fransisco: Harper \& Row, 1980.

- Sharing Faith: A Comprehensive Approach to Religious Education \& Pastoral Ministry. San Fransisco: Harper \& Row, 1991.

Homrighausen, E. G, and I. H. Enklaar. Pendidikan Agama Kristen. Jakarta: BPK Gunung Mulia, 2015.

Hope, A. S. Pendidikan Kristiani Kontekstual. Jakarta: BPK Gunung Mulia, 2010.

Lopez, D. C. Apostle to the Conquered: Reimagining Paul's Mission. Minneapolis: Fortress Press, 2010.

Nataniel, Demianus. "Paradigma Ziarah Dalam Penafsiran Alkitab." Jurnal Abdiel: Khazanah Pemikiran Teologi, Pendidikan Agama Kristen, dan Musik Gereja 2, no. 2 (2018): 43-55. https://doi.org/10.37368/ja.v2i2.50.

. "Parousia, Pembenaran Allah, Dan Kebangkitan Orang Mati: Perbuatan-Perbuatan Baik Dalam Meraih Keselamatan Menurut Surat-Surat Paulus.” Jurnal Abdiel: Khazanah Pemikiran Teologi, Pendidikan Agama Kristen, dan Musik Gereja 2, no. 1 (2018): 33-47. https://doi.org/10.37368/ja.v2i1.59.

. "Paulus Dalam Konflik Antarumat Beragama: Membaca Konflik Di Maluku Utara Berdasarkan Sikap Nasionalisme Paulus.” GEMA TEOLOGIKA: Jurnal Teologi Kontekstual \& Filsafat Keilahian 4, no. 2 (2019).

. "Soteriologi Menurut Paulus Sebagai Dasar Tradisi Bagi Pelaksanaan Pendidikan Agama Dalam Konteks Pluralisme Di Indonesia.” Jurnal Abdiel: Khazanah Pemikiran Teologi, Pendidikan Agama Kristen, dan Musik Gereja 3, no. 1 (2019): 60-76. https://doi.org/10.37368/ja.v3i1.45.

Santoso, Slamet. "Resensi Buku Pendidikan Kristen Konteks Sekolah: 12 Pesan Untuk Guru Dan Pengelola." Jurnal Abdiel: Khazanah Pemikiran Teologi, Pendidikan Agama Kristen, dan Musik Gereja 3, no. 1 (2019): 77-79. https://doi.org/10.37368/ja.v3i1.38.

. "Tinjauan Kritis Terhadap Pendidikan Agama Multikultural Barbara Wilkerson." Jurnal Abdiel: Khazanah Pemikiran Teologi, Pendidikan Agama Kristen, dan Musik Gereja 2, no. 2 (2018): 56-71. https://doi.org/10.37368/ja.v2i2.32.

Setyowati, Dwi Atni. "Konflik Kepemimpinan Dalam Pekabaran Injil: Sebuah Pemaknaan Terhadap Perselisihan Paulus Dan Barnabas Dalam Kisah Para Rasul 15:35-41.” Jurnal Abdiel: Khazanah Pemikiran Teologi, Pendidikan Agama Kristen, dan Musik Gereja 3, no. 1 (2019): 33-47. https://doi.org/10.37368/ja.v3i1.49.

Sidjabat, B.S. Strategi Pendidikan Kristen. Yogyakarta: Andi Offset, 1999.

Umar, T, and S. L. La Sulo. Pengantar Pendidikan. Jakarta: Rineka Cipta, 2005. 
Warsudi, Agus. "Virus Corona Mewabah, Jumlah Orang Dengan Gangguan Jiwa Di Jabar Meningkat." Sindonews.Com. Bandung, April 17, 2020.

https://jabar.sindonews.com/read/3309/701/virus-corona-mewabah-jumlah-orangdengan-gangguan-jiwa-di-jabar-meningkat-1587121477. 